\title{
SKUTKI RYZYKA SYSTEMU EMERYTALNEGO DLA ROZWOJU SPOŁECZNO-EKONOMICZNEGO - PRZYPADEK KRYZYSU FINANSOWEGO I FISKALNEGO
}

\begin{abstract}
Streszczenie
System emerytalny jest ważnym elementem kształtowania procesów społeczno-ekonomicznych, gdyż jego zadaniem jest zapewnienie dochodów osobom w wieku emerytalnym. Przedmiotem artykułu jest system emerytalny w ujęciu procesów zachodzących w czasie akumulacji i wykorzystania kapitału emerytalnego, które odbywają się w warunkach ryzyka generowanego przez kryzysy finansowe i fiskalne. Celem artykułu jest wskazanie oddziaływania skutków ryzyka systemowego na realizację celu systemu emerytalnego, w tym wskazania jego skutków w wymiarze zrównoważonego rozwoju społeczno-ekonomicznego. Zakłócenia w realizacji celu systemu emerytalnego mogą mieć istotny wpływ na ograniczenie jej ze względu na konieczność równoważenia bieżących potrzeb finansowych kosztem kolejnych pokoleń. Rozważania teoretyczne zostały zilustrowane badaniami empirycznymi, dotyczącymi oddziaływania kryzysu finansowego i fiskalnego na polski system emerytalny. W związku z tym wykorzystano dane finansowe dotyczące otwartych funduszy emerytalnych oraz systemu finansów publicznych za lata 1999-2012.
\end{abstract}

Słowa kluczowe: system emerytalny, ryzyko, kryzys finansowy, kryzys fiskalny.

\section{EFFECTS OF PENSION SYSTEM RISK ON SUSTAINABLE SOCIO-ECONOMIC DEVELOPMENT: THE CASE OF FINANCIAL AND FISCAL CRISIS}

\section{Summary}

A pension system is a crucial factor which shapes social and economic processes, because its aim is to provide income during retirement. This paper is concerned with pension systems in terms of the processes occurring during the accumulation and use of retirement capital in conditions of risk generated by financial and fiscal crises. The author aims to identify the impact of the effects of systemic risk on the implementation of pension system objectives and on the realisation of the idea of sustainable socio-economic development. Obstacles to achieving the goals of the pension system may lead to a substantial reduction in other state expenditures because of the need to satisfy the current financial needs at the expense of subsequent generations. Theoretical considerations are illustrated by empirical studies on the influence of the financial and fiscal crisis on the Polish pension system. For this purpose, financial data relating to pension funds and the public finance system for years 1999-2012 was used.

Key words: pension system, risk, financial crisis, fiscal crisis

${ }^{1}$ Dr Jan Kaczmarzyk - Wydział Finansów i Ubezpieczeń, Uniwersytet Ekonomiczny w Katowicach; e-mail: jan.kaczmarzyk@ue.katowice.pl. Dr Piotr Kania - Wydział Finansów i Ubezpieczeń, Uniwersytet Ekonomiczny w Katowicach; e-mail: piotr.kania@ue.katowice.pl. 


\section{Wstęp}

System emerytalny jest ważnym elementem kształtowania procesów społeczno-ekonomicznych, gdyż celem jest zapewnienie dochodów osobom w wieku emerytalnym. Z mikroekonomicznego punktu widzenia jego realizacja wiąże się $\mathrm{z}$ cyklem życia jednostki gospodarującej, która musi podejmować decyzje w okresie aktywności zawodowej, ile konsumować, a ile oszczędzać, m.in. na emeryturę. Z makroekonomicznego punktu widzenia następuje proces redystrybucji dochodów przez publiczny i rynkowy system finansowy między różnymi pokoleniami, które chcą utrzymać określony standard życia.

Przedmiotem artykułu jest system emerytalny w ujęciu procesów zachodzących w czasie akumulacji i wykorzystania kapitału emerytalnego, które odbywają się w warunkach ryzyka gospodarczego, a szczególnie ryzyka systemowego generowanego przez kryzysy finansowe i fiskalne. Celem artykułu jest wskazanie oddziaływania skutków ryzyka systemowego na realizację celu systemu emerytalnego, międzypokoleniowego podziału i finansowania jego skutków w wymiarze realizacji idei zrównoważonego rozwoju w wymiarze społeczno-ekonomicznym. Zakłócenia w realizacji celu systemu emerytalnego moga mieć istotny wpływ na ograniczenie aplikacyjności tej idei ze względu na konieczność równoważenia bieżących potrzeb finansowych kosztem kolejnych pokoleń. Rozważania teoretyczne zostały zilustrowane badaniami empirycznymi, związanymi z oddziaływaniem kryzysu finansowego i fiskalnego na polski system emerytalny. W tym celu wykorzystano dane ze sprawozdań finansowych otwartych funduszy emerytalnych, obejmujące okres od 2002 do 2012 roku, oraz dane finansowe dotyczące systemu finansów publicznych za lata 1999-2012.

\section{System emerytalny a zrównoważony rozwój społeczno-ekonomiczny}

Każda jednostka gospodarująca (gospodarstwo domowe, przedsiębiorstwo) ma styczność z systemem emerytalnym w ramach swoich procesów gospodarczych. Gospodarstwo domowe przede wszystkim może optymalizować konsumpcję w czasie, dzięki przesuwaniu części swojego dochodu z pracy na okres, gdy jego członkowie osiagną wiek emerytalny [Blake, 2006, s. 13-14]. W przypadku przedsiębiorstw system emerytalny jest z jednej strony przyczyna podwyższonych kosztów pracy, które jednak przyczyniają się do poprawy jakości kapitału ludzkiego [Kania, 2012, s. 143], a z drugiej strony jest źródłem pozyskania kapitału na działalność operacyjną i rozwojowa. Innym podmiotem powiązanym z systemem emerytalnym jest państwo, które zwykle przyjmuje na siebie zadania regulacyjne i nadzorcze, ale także często jest bezpośrednim realizatorem programów emerytalnych, składających się na jego strukturę. Ten szeroki zakres zadań państwa w obszarze systemu emerytalnego wynika nie tylko z jego funkcji w gospodarce, lecz przede wszystkim jest zwiazzane $z$ zapewnieniem jak najlepszego realizowania jego podstawowego celu, jakim jest dostarczanie świadczeń emerytalnych poprodukcyjnej części społeczeństwa, czyli osobom w wieku emerytalnym [Kania, 2011, s. 181]. W aspekcie ekonomicznym system ten wymaga współdziałania gospodarstw domowych, przedsiębiorstw i państwa, natomiast w sferze społecznej przyczynia się nie tylko do stabilizacji funkcjono- 
wania jednostki i rodziny w sferze mentalnej, ale także wymaga zaangażowania znacznej części populacji, co wpływa na interakcje różnych grup społecznych i ich interesów (rysunek 1.).

\section{RYSUNEK 1.}

\section{System emerytalny w strukturze systemu społeczno-ekonomicznego}

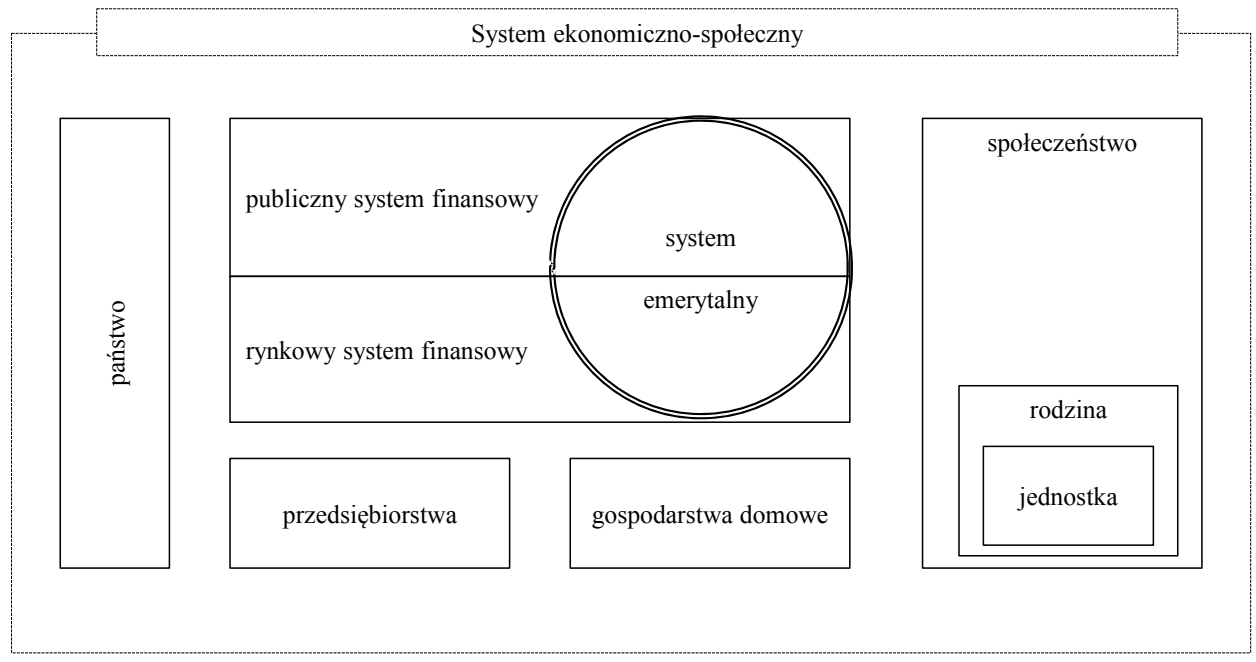

Źródło: opracowanie własne.

Ze względu na uwypuklenie sposobu realizacji celu systemu emerytalnego, jest on $z$ reguły rozpatrywany $w$ ujęciu funkcjonalnym, w którym wskazuje się na kolejne elementy składowe świadczenia emerytalnego, tzw. filary, przy czym z punktu widzenia nauki istotne jest wskazanie istotnych cech systemowych, takich jak: spójność, trwalość, ciagłość oraz celowość w działaniu [Kania, 2011, s. 181]. W tym ujęciu system emerytalny tworzy: (...) ogót planów (programów), które wyplacaja dochody osobom w podeszłym wieku [Mattil, 2006, s. 7], co wymaga zaangażowania różnego rodzaju instytucji i instrumentów ekonomicznych, które realizując swój cel, wywołują określone skutki ekonomiczne czy społeczne.

Ponieważ system emerytalny jest elementem systemu społeczno-ekonomicznego, chociażby ze względu na rodzaj głównego źródła utrzymania większej części społeczeństwa, jakim we współczesnej gospodarce rynkowej jest praca, nie można pominąć jego oddziaływania, nie tylko na sytuację ekonomiczną podmiotów gospodarczych, lecz również na możliwości rozwoju takiej gospodarki i kształtowanie obecnych i przyszłych stosunków społecznych. Elementem umowy społecznej może być ekonomiczna koncepcja zrównoważonego rozwoju. Stąd podczas planowania i realizacji zadań rozwoju przyjmuje się, że kombinacja technik ekonomicznych, społecznych i ekologicznych powinna dać taką formę gospodarowania oraz współżycia między ludźmi, która umożliwia funkcjonowanie kolejnych pokoleń dzięki sprawiedliwości wewnątrz- i międzypokoleniowej, natomiast przy ustalaniu tego celu bierze się pod uwagę kryteria stabi- 
lizacyjne i rozwojowe [Ksz̧tałtowanie... 2011, s. 31-32]. W takim przypadku należy wziąć pod uwagę możliwość oddziaływania systemu emerytalnego na stabilność i równowagę tych procesów, a wynika to z tego, że:

- funkcjonowanie programów emerytalnych wymaga tworzenia wspólnoty ryzyka, która niezależnie od zasady jej działania - opartej na sprawiedliwości społecznej czy na sprawiedliwości aktuarialnej - powoduje przejście z poziomu jednostki do poziomu zbiorowości, a więc ma wymiar społeczny;

- realizacja celu systemu emerytalnego wymaga redystrybucji dochodów, która odbywa się albo międzypokoleniowo (finansowanie repartycyjne), albo wewnątrzpokoleniowo (finasowanie kapitałowe), jednak zawsze prowadzi do ograniczenia bieżącej konsumpcji osób aktywnych zawodowo na rzecz pokolenia emerytów, co wyrównuje poziom konsumpcji zarówno w czasie, jak i w przestrzeni społecznej;

- głównym obszarem jego funkcjonowania jest system finansowy, publiczny lub rynkowy, co w przypadku tego drugiego umożliwia tworzenie kapitału na potrzeby gospodarki, a gospodarstwom domowym uczestniczenie w zyskach generowanych przez przedsiębiorstwa;

- tworzenie rezerw kapitałowych w systemie emerytalnym może być wykorzystane na potrzeby finansowania zadań społecznie uzasadnionych jednak niemających jednoznacznych kryteriów opłacalności ekonomicznej.

System emerytalny jest współcześnie istotnym elementem procesów gospodarczych. Tylko część pracownicza tego sytemu w Polsce powoduje redystrybucję na poziomie 6-7\% PKB (rysunek 2.). Jego korzyści w wymiarze zaspokajania potrzeb gospodarstw domowych są oczywiste. Równocześnie należy mieć na uwadze to, że zachwianie równowagi w tym systemie może rodzić skutki nie tylko dla jego beneficjentów, ale także dla całej gospodarki czy społeczeństwa. Głównym powodem tych fluktuacji w przebiegu procesu dostarczania świadczeń emerytalnych są zmiany zachodzace w otoczeniu społeczno-ekonomicznym, jednakże są one uwarunkowane wyborem formy finansowania tych świadczeń, a tym samym redystrybucji dochodu przez system emerytalny. Wydaje się, że dyskusja - zarówno naukowa, jak i społeczna, związana $z$ rozważaniami nad wyborem modelu finansowego systemu emerytalnego, nie powinna pomijać problemu ryzyka, który jest jego immanentną cechą. Dlatego też analizę oddziaływania kryzysu finansowego i fiskalnego na polski system emerytalny poprzedzono wyjaśnieniem istoty ryzyka systemu emerytalnego. 
RYSUNEK 2. Wydatki na świadczenia $\mathrm{z}$ Funduszu Ubezpieczeń Społecznych $\mathrm{w}$ relacji do PKB w latach 1999-2012 (w \%)

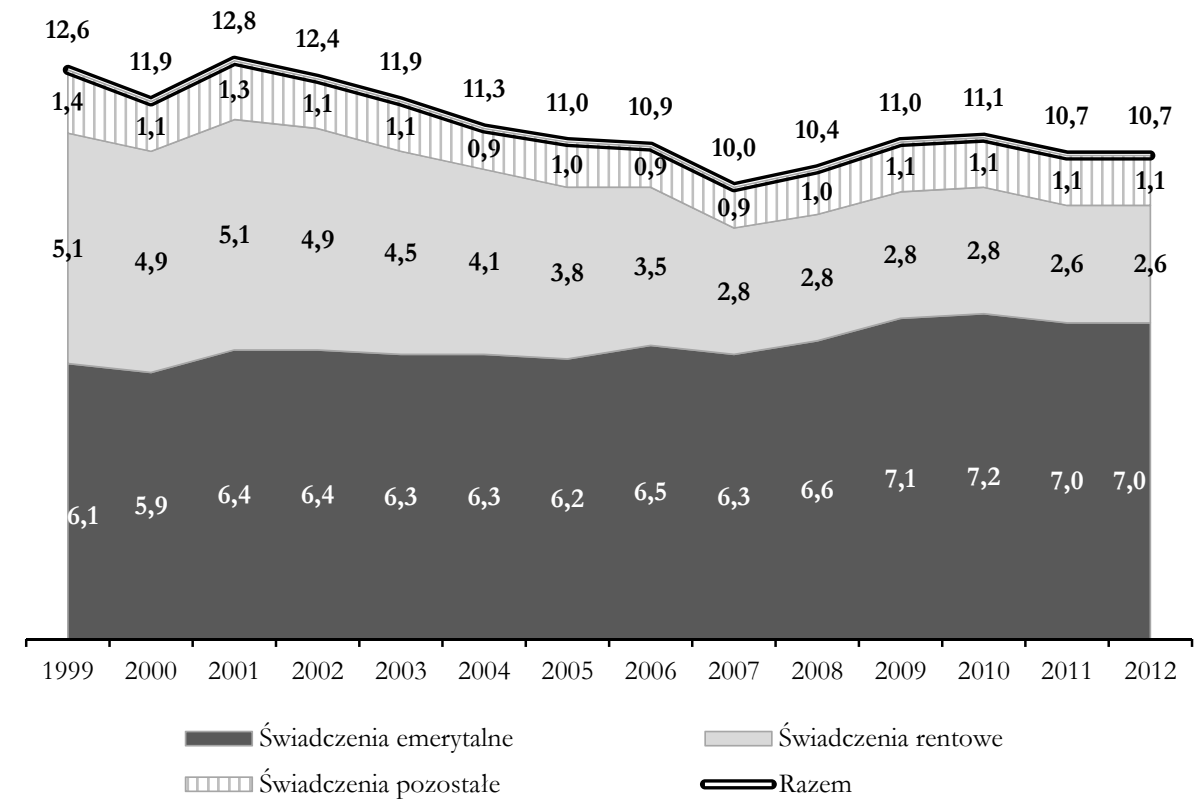

Źródło: opracowanie własne na podstawie danych Zakładu Ubezpieczeń Społecznych.

\section{Istota ryzyka systemu emerytalnego}

Ponieważ funkcjonowanie systemu emerytalnego przede wszystkim przebiega w sferze finansowej gospodarowania, to jego mechanizm działania polega na dopasowaniu strumieni pieniężnych związanych z przychodami programów emerytalnych oraz ich wydatkami na świadczenia emerytalne w czasie i przestrzeni. Oznacza to, że redystrybucja dochodów, dokonywana w ramach jego instrumentów i instytucji, nie powinna powodować nierównowagi między różnymi pokoleniami oraz między różnymi grupami społecznymi i podmiotami gospodarczymi w zakresie danego pokolenia. Jednak bezpośrednie powiązanie z procesami: gospodarczymi, społecznymi i naturalnymi powoduje, że pojawia się możliwość powstania odchylenia od równowagi w tym systemie. Jeżeli ta nierównowaga ma charakter negatywny, tzn. że powstałe odchylenie wymaga dodatkowych nakładów finansowych lub generuje dodatkowe koszty społeczne, to można mówić o istnieniu ryzyka systemu emerytalnego.

Ryzyko systemu emerytalnego można wyrazić jako możliwość utraty równowagi finansowej, powodującej konieczność interwencji finansowej, albo pozafinansowej ze strony władz regulacyjnych. Przez równowagę finansowa, użytą w definicji ryzyka systemu emerytalnego, należy rozumieć sytuację, w której istnieje możliwość finansowa- 
nia przyrzeczonych świadczeń emerytalnych na podstawie nabytych uprawnień ze środków finansowych pierwotnie na ten cel przeznaczonych (środków celowych). Można stwierdzić, że ryzyko systemu emerytalnego - podobnie jak ryzyko systemu finansowego, na co zwrócili uwagę: D. Hendricks, J. Kambru, P. Mosser - wiąże się z procesem przechodzenia od sytuacji satysfakcjonującej jego interesariuszy do stanu, w którym następuje brak satysfakcji wszystkich podmiotów, które muszą ponieść skutki tego ryzyka [Solarz, 2008, s. 19].

Zdefiniowane $\mathrm{w}$ ten sposób ryzyko systemu emerytalnego ma przede wszystkim wymiar zewnętrzny, tzn. opisany skutkami w postaci konieczności dofinansowania świadczeń ze źródeł zewnętrznych albo podjęcia przez organ regulacyjny decyzji o zmianie zasad przyznawania świadczeń emerytalnych lub obciążeń kontrybucyjnych. Pierwsza grupa zmian ma charakter przejściowy i może łączyć się z: uruchomieniem funduszy rezerwowych, przyznaniem dotacji budżetowych bądź zaciąnięciem pożyczek. Druga grupa decyzji ma charakter trwały, najczęściej powodujący zmiany strukturalne w samym systemie emerytalnym.

Ryzyko systemu emerytalnego warto także rozpatrywać pod względem przyczyn, czyli z punktu widzenia zagrożeń generujących możliwość utraty równowagi finansowej. W takim przypadku ryzyko systemu emerytalnego należy określić jako możliwość powstania odchyleń od zaplanowanego przebiegu procesów akumulacji i dystrybucji kapitału emerytalnego, na skutek zmian zachodzących w parametrach determinujących ich przebieg. Skutki takich odchyleń mogą zostać zaabsorbowane przez mechanizmy ochronne, zaimplementowane w samym systemie (wymiar wewnętrzny ryzyka), ale mogą również mieć skutki zewnętrzne, a więc takie, które powodują konieczność przerzucenia ich na interesariuszy (gospodarstwa domowe, przedsiębiorstwa) lub całe społeczeństwo, co ponownie wskazuje istotę definicji ryzyka tego systemu.

Ze względu na przyczyny, ryzyko systemu emerytalnego można poddać dalszej dekompozycji. Góra wymienia następujące, szeroko rozumiane, typy ryzyka: demograficzne, gospodarcze, nieakceptacji, organizacyjne, nieuczciwości, hazard moralny oraz ryzyko polityczne [Góra, 2003, s. 84]. Mattil wskazuje na zewnętrzne przyczyny ryzyka systemu emerytalnego, oddziałujące na jego równowagę (sustainability) oraz generujące określone skutki dystrybucyjne, które dzieli na makroekonomiczne oraz społeczne. W pierwszej grupie wymienia: tempo wzrostu PKB, wzrost poziomu cen i wynagrodzeń, poziom bezrobocia, dochodowość inwestycji, natomiast w drugiej grupie wskazuje na: strukturę demograficzna, politykę państwa czy katastrofy [Mattil, 2006, s. 30-34]. Mając na uwadze główny obszar interakcji systemu emerytalnego z otoczeniem, trzeba wymienić grupe przyczyn ekonomicznych, a wśród nich: ryzyko tempa wzrostu gospodarczego, ryzyko inflacji, ryzyko finansowe oraz ryzyko fiskalne, a także grupę przyczyn pozaekonomicznych, z: ryzkiem demograficznym społecznym (nieakceptacji), ryzykiem socjalnym czy ryzykiem politycznym.

Pozostałe przyczyny, które zasadniczo mają charakter przyczyn wewnętrznych, należy wymienić pod wspólną nazwą ryzyka operacyjnego, które jest związane z organizacją systemu emerytalnego, a przede wszystkim z koniecznością funkcjonowania w nim podmiotów realizujących poszczególne zadania. Skipper i Kwon do tego typu ryzyka zaliczają: ryzyko majątkowe (utraty mienia i odpowiedzialności cywilnej), 
ryzyko osobowe i ryzyko personelu, ryzyko koncentracji i ryzyko reputacji [Skipper, Kwon, 2007, s. 21-22]. Dotyczy ono możliwości powstania straty w wyniku działań podejmowanych przez podmioty wchodzące w skład systemu emerytalnego, związane z: wykorzystaniem istniejących w nim mechanizmów, instytucji lub narzędzi, a także z prowadzeniem przez nie działalności gospodarczej. Ryzyko to może dotyczyć: nieprawidłowo funkcjonujących wewnętrznych procedur, ludzi czy rozwiązań systemowych, jak również może pochodzić z zewnątrz. Do zagrożeń generujących to ryzyko zalicza się m.in.: oszustwa (wewnętrzne i zewnętrzne), bezpieczeństwo pracy i relacje z pracownikami, zniszczenie fizyczne aktywów, wady systemów czy zarządzanie procesami biznesowymi [Zarzqdzanie..., 2007, s. 24].

Niektóre z przyczyn ryzyka nieekonomicznego maja swoje przyczyny naturalne, jak ryzyko socjalne, które jest powiązane $z$ występowaniem w programach emerytalnych grup osób dotkniętych innymi typami ryzyka osobowego (socjalnego), a te powodują że nie mogą one w normalny sposób uczestniczyć w procesie gromadzenia środków na wypłatę emerytur, np. osoby przebywające na zasiłku chorobowym, na rencie inwalidzkiej bądź bezrobotni. Ich wpływ na ryzyko systemu emerytalnego ma działanie dwukierunkowe. $Z$ jednej strony, nie uczestniczą oni w tworzeniu funduszu emerytalnego, gdyż są zwolnieni z opłacania składek, a z drugiej strony, często zachowują uprawnienia do świadczenia emerytalnego w tym okresie.

Zdecydowana większość przyczyn ryzyka systemu emerytalnego ma swoje źródło w procesach społecznych czy gospodarczych. Powoduje to, że ma ono charakter dynamiczny. Oprócz koniecznego dla kategorii ryzyka rezultatu negatywnego, moga one mieć skutki odwrotne (pozytywne). Ryzyko takie może mieć charakter neutralny, pod warunkiem że korzystny przebieg przyszłych zdarzeń zostanie wykorzystany do zabezpieczenia się przed ewentualnymi skutkami negatywnymi. Przykładem może być ryzyko demograficzne, które wiąże się z relacją zachodząca pomiędzy osobami aktywnymi zawodowo a osobami pobierającymi świadczenia emerytalne [Góra, 2003, s. 84], chociaż może być także postrzegane pod względem procesów naturalnych, tj. dzietności (płodności młodego pokolenia) oraz długowieczności (przeciętnego dalszego trwania życia pokolenia poprodukcyjnego), [Bohn, 2006, s. 11-12]. Przede wszystkim jest zauważane ono w aspekcie niekorzystnego trendu demograficznego, tzn. gdy znacząco zmniejsza się liczebność tej pierwszej grupy w stosunku do drugiej, tj. następuje efekt starzenia się społeczeństwa. Takie spojrzenie ma głównie swój bezpośredni wymiar ekonomiczny, który przejawia się w pytaniu: czy osoby aktywne zawodowo (wnoszące kontrybucję do systemu) będą w stanie sfinansować przyrzeczony w przeszłości poziom konsumpcji obecnym emerytom? Jednak można jednak wskazać sytuację odwrotna, w takim przypadku powinno się wykorzystać powstałe nadwyżki finansowe do tworzenia rezerw na wypadek konieczności uzupełnienia niedoboru środków w systemie emerytalnym, w kolejnej niekorzystnej fazie cyklu demograficznego.

Obietnice składane przyszłym emerytom, a więc osobom aktywnym zawodowo, są wyceniane w jednostkach pieniężnych, które odzwierciedlają podział PKB pomiędzy aktywnych zawodowo a emerytów, stąd czynniki ekonomiczne są istotnymi determinantami ryzyka system emerytalnego. Aby obietnice składane osobom przystępującym do 
systemu emerytalnego mogły być w przyszłości zrealizowane możliwości podziału PKB między te dwie grupy interesariuszy nie mogą się w przyszłości zmienić. Znaczące pogorszenie się, wypracowywanego przez pokolenie aktywne zawodowo, dochodu narodowego może doprowadzić do konieczności finansowania przyrzeczonych uprawnień emerytalnych $z$ innych źródeł niż środki dostępne w systemie, ale nie zmienia to faktu, że skutki te odczuje pokolenie aktywne zawodowo. Zwykle ryzyko warunkowane czynnikami ekonomicznymi jest wiązane $z$ funduszami kapitałowymi, jednak ma ono także znaczenie dla finansowania repartycyjnego, gdyż nawet przy niskim poziomie PKB moga być realizowane uprawnienia emerytalne, kosztem obecnego i przyszłych pokoleń aktywnych zawodowo.

Fundusze kapitałowe są oceniane przede wszystkim przez pryzmat stopy zwrotu z czasowego (długookresowego), zaangażowanego w procesy gospodarcze kapitału emerytalnego. Oznacza to uzyskiwanie w sferze realnej określonego poziomu dochodowości, który następnie będzie przekładał się na trwały wzrost wartości aktywów. W badaniach przeprowadzonych na rynku amerykańskim ustalono, że długoterminowa, realna stopa zwrotu $\mathrm{z}$ akcji w ujęci realnym wynosi około $7 \% \mathrm{w}$ skali roku, co odpowiada trwałej tendencji rozwojowej przedsiębiorstw i gospodarki [Halsen, 2003, s. 154-155]. Efektywność gospodarki może nie wpływać na bieżącą wartość kapitału emerytalnego, szczególnie w krótkich okresach. Wynika to ze specyfiki ryzyka finansowego, które odzwierciedla nie tylko zmiany w płynności i wypłacalności pojedynczych podmiotów, lecz również obejmuje procesy rynkowe związane z wyceną aktywów finansowych. Fundusze kapitałowe, nabywając tego typu aktywa, narażone są na okresowe zmiany ich wartości, zwłaszcza w czasie kryzysu finansowego, kiedy ryzyko to przybiera ekstremalne rozmiary.

Ryzyko fiskalne dotyczy przede wszystkim repartycyjnych funduszy emerytalnych, które zwykle stanowią część finansów publicznych i są powiązane z budżetem państwa. Równowaga finansów publicznych, a głównie jej długookresowy brak powoduje, że programy emerytalne, oparte na bieżącym finansowaniu, mogą być objęte zakresem działań sanacyjnych.

Kierunek działań sanacyjnych w obrębie systemu emerytalnego może mieć różny przebieg. Na przykład kryzys finansowy może być powodem likwidacji kapitałowej części obowiazkowego systemu emerytalnego (przykładem jest chociażby działanie rządu Weegier po kryzysie finansowym z 2008 roku), którego rzeczywiste przyczyny znajdowały się po stronie kryzysu fiskalnego, czy działania podjęte w Polsce w 2011 roku, które miały na celu ograniczenie skutków reformy emerytalnej z 1998 roku dla równowagi finansów publicznych. W kolejnych punktach artykułu zostały przedstawione wyniki badań dotyczące oddziaływania skutków kryzysu finansowego i fiskalnego na strukturę systemu emerytalnego w Polsce. Przypadek ten jest szczególnie ciekawy z tego względu, że pomiędzy kapitałową częścią obowiązkowego systemu emerytalnego a finansami publicznymi występuje powiązanie, które jest wynikiem wprowadzonej reformy, a ma bezpośrednie skutki dla równowagi finansowej budżetu państwa. 


\section{Kryzys finansowy a efektywność otwartych funduszy emerytalnych}

Przedmiotem badań oddziaływania kryzysu finansowego na wyniki uzyskiwane przez otwarte fundusze emerytalne objęto wszystkie fundusze, co w zestawieniach tabelarycznych reprezentuje pozycja „OFE ogółem”. Ze względu na zachodzące procesy konsolidacyjne na rynku otwartych funduszy emerytalnych, wyniki badań jednostkowych zostały zaprezentowane dla funduszy funkcjonujących w 2012 roku. Z uwagi na specyfikę publikowanej sprawozdawczości finansowej funduszy, do oceny stopnia oddziaływania kryzysu finansowego na ich efektywność przyjęto kwartalne wyniki finansowe, wyrażone w relacji do wartości aktywów netto za okres od początku 2000 roku do końca 2012 roku. Dokonano dekompozycji ich wyniku finansowego na trzy składowe:

- $\quad$ wynik z inwestycji, czyli efekt działalności inwestycyjnej, uwzględniający przychody z lokat (odsetki, dywidendy itp.) pomniejszone o koszty działalności operacyjnej;

- $\quad$ zysk (stratę) z inwestycji, czyli efekt będący różnicą między ceną nabycia składnika aktywów a ceną jego sprzedaży po uwzględnieniu kosztów ponoszonych w trakcie tych operacji;

- $\quad$ zysk (stratę) z wyceny inwestycji, czyli skutek przeszacowania wartości składników aktywów ze względu na różnicę między ceną nabycia a ceną rynkową w dniu wyceny.

Jako parametry, odzwierciedlające zachowanie rynku, przyjęto indeksy giełdowe WIG oraz WIG20. W ich przypadku wzięto pod uwagę wskaźnik tempa zmian za okresy odpowiadające kwartalnym okresom sprawozdawczym otwartych funduszy emerytalnych. Ponieważ rozkład częstości przyjętych parametrów był zbliżony do rozkładu normalnego, co potwierdzono za pomocą testu zgodności chi-kwadrat, do badań zastosowano odpowiadające tym rozkładom miary statystyczne.

Na pierwszym etapie badań dokonano oceny oddziaływania zmienności przyjętych indeksów giełdowych na wyodrębnione komponenty wyniku finansowego otwartych funduszy emerytalnych. Wskaźnik wyrażający wynik z inwestycji uzyskał niewielka, ale ujemna, korelację $z$ indeksami giełdowymi, co oznacza, że ten składnik wyniku finansowego otwartych funduszy emerytalnych praktycznie nie jest uzależniony od zmienności cen rynkowych aktywów. Natomiast słaba, lecz dodatnią, zależnością cechuje się składnik wyniku finansowego w postaci zrealizowanych zysków (strat) ze sprzedaży składników aktywów (por.: tabela 1., rysunek 3.). W pierwszym przypadku uzyskana wartość współczynnika Pearsona jest wynikiem rodzaju przychodów otwartych funduszy emerytalnych, składających się z odsetek od wierzycielskich papierów wartościowych, które nie są zależne od popytu i podaży na instrumenty finansowe. Także dywidendy z akcji nie są uzależnione od bieżącej sytuacji na rynku kapitałowym, ale raczej wyników przedsiębiorstw. Natomiast zyski (straty) ze sprzedaży aktywów bardziej reagują na zmiany cen na rynku, gdyż ich poziom zależy od wyceny rynkowej. Jednak, ze względu na dużą wartość aktywów i relatywnie małe odpływy kapitału, otwarte fundusze emerytalne maja możliwość wyboru sprzedawanych aktywów, przy zachowaniu struktury lokat wymaganej przepisami prawa. 
TABELA 1. Współczynniki korelacji wyniku finansowego otwartych funduszy emerytalnych i stóp zwrotu z indeksów giełdowych WIG i WIG20 w ujęciu kwartalnym za lata 2000-2012

\begin{tabular}{|c|c|c|c|c|c|c|c|c|c|}
\hline \multirow[t]{2}{*}{ Lp. } & \multirow[t]{2}{*}{ Wyszczególnienie } & \multicolumn{2}{|c|}{ Wynik z inwestycji } & \multicolumn{2}{|c|}{$\begin{array}{c}\text { Zrealizowane } \\
\text { zyski (straty) } \\
\text { z inwestycji }\end{array}$} & \multicolumn{2}{|c|}{$\begin{array}{l}\text { Niezrealizowane } \\
\text { zyski (straty) } \\
\text { z wyceny inwe- } \\
\text { stycji }\end{array}$} & \multicolumn{2}{|c|}{ Wynik finansowy } \\
\hline & & WIG & WIG20 & WIG & WIG20 & WIG & WIG20 & WIG & WIG20 \\
\hline 1. & EGON & $-0,1073$ & $-0,1173$ & 0,1440 & 0,2098 & 0,8727 & 0,8322 & 0,8777 & 0,8495 \\
\hline 2. & $\begin{array}{l}\text { Allianz Polska } \\
\text { OFE }\end{array}$ & , 1662 & $-0,1872$ & 46 & 5027 & 0,8012 & 7151 & 0,8841 & 0,8514 \\
\hline 3. & Amplico OFE & $-0,1094$ & $-0,1182$ & 0,4215 & 0,4945 & 0,8913 & 0,8333 & 0,9129 & 0,8819 \\
\hline 4. & Aviva OFE & $-0,1659$ & $-0,1697$ & 0,4406 & 4936 & 0,9061 & 0,8808 & 0,9091 & 0,8909 \\
\hline 5. & AXA OFE & $-0,1995$ & $-0,2227$ & 0,2869 & 0,3170 & 0,8796 & 0,8163 & 0,9083 & 0,8898 \\
\hline 6. & Generali OFE & $-0,1181$ & $-0,1295$ & 0,2500 & 0,3002 & 0,8918 & 0,8559 & 0,9188 & 0,8949 \\
\hline 7. & ING OFE & $-0,1030$ & $-0,1237$ & 0,2227 & 0,3661 & 0,8934 & 0,8636 & 0,8866 & 0,8810 \\
\hline 8. & Nordea OFE & 0,0215 & 0,0334 & 0,1393 & 0,3206 & 0,8740 & 0,8399 & 0,4234 & 0,5707 \\
\hline 9. & Pekao OFE & $-0,1660$ & $-0,1710$ & 0,4423 & 0,3808 & 0,8559 & 0,8145 & 0,8935 & 0,8340 \\
\hline 10. & $\begin{array}{l}\text { PKO BP Bankowy } \\
\text { OFE }\end{array}$ & $-0,0744$ & $-0,0906$ & 0,4203 & 0,4915 & 0,5736 & 0,6921 & 0,8704 & 0,8688 \\
\hline 11. & OFE Pocztylion & $-0,1417$ & $-0,1522$ & 0,2383 & 0,3436 & 0,9086 & 0,8705 & 0,9228 & 0,9023 \\
\hline 12. & OFE POLSAT & $-0,2422$ & $-0,2321$ & 0,4809 & 0,5763 & 0,8575 & 0,7438 & 0,9109 & 0,8312 \\
\hline 13. & $\begin{array}{l}\text { OFE PZU „Złota } \\
\text { Jesień” }\end{array}$ & $-0,1042$ & $-0,1284$ & 0,3106 & 0,3760 & 0,8847 & 0,8205 & 0,8927 & 0,8452 \\
\hline 14. & OFE WARTA & $-0,2037$ & $-0,2160$ & 0,3166 & 0,3744 & 0,8303 & 0,7861 & 0,9159 & 0,8939 \\
\hline 15. & OFE ogółem & $-0,1405$ & $-0,1528$ & 0,4156 & 0,5260 & 0,9054 & 0,8747 & 0,9091 & 0,8895 \\
\hline
\end{tabular}

Uwagi: w przypadku badanych funduszy przy 50 stopniach swobody dla $\alpha=0,05$ za istotny statystycznie należy uznać współczynnik korelacji $r= \pm 0,3541$ ( przy $\alpha=0,01 r= \pm 0,4433$ ).

Źródło: opracowanie własne.

Największy stopień zależności od zmienności rynku wykazuje natomiast niezrealizowany zysk (strata) z wyceny inwestycji (tabela 1., rysunek 4.). Ze względu na konieczność dokonywania wyceny aktywów w każdy dzień roboczy, co jest związane z potrzebą podawania wartości jednostki rozrachunkowej, która służy przeliczaniu kwot wpłacanych składek i wypłacanego kapitału emerytalnego, ten komponent wyniku finansowego jest szczególnie dodatnio skorelowany ze zmiennością rynku, mierzoną indeksami WIG i WIG20.

W podobny sposób zachowuje się również wynik finansowy otwartych funduszy emerytalnych, którego wartość bezpośrednio wpływa na wartości aktywów netto. Spowodowane jest to tym, że zysk (strata) z wyceny inwestycji jest głównym składnikiem tego wyniku. Powodem tej sytuacji jest niezbędność utrzymywania odpowiedniej struktury aktywów, niezależnie od bieżącej sytuacji rynkowej. Oceniając efektywność otwartych funduszy emerytalnych, należy także pamiętać, że są to instytucje gromadzące oszczędności długoterminowo, stąd są bardziej skłonne do wyboru strategii inwes- 
tycyjnej typu „kup i trzymaj”, niz inne formy zbiorowego inwestowania, takie jak np. fundusze inwestycyjne, gdzie strategie timingu rynkowego są bardziej akceptowane.

RYSUNEK 3.

Zmienność wyniku z inwestycji oraz zrealizowanego zysku (straty) z inwestycji otwartych funduszy emerytalnych na tle zmienności wzorca odniesienia (indeksu WIG) w latach 2000-2012

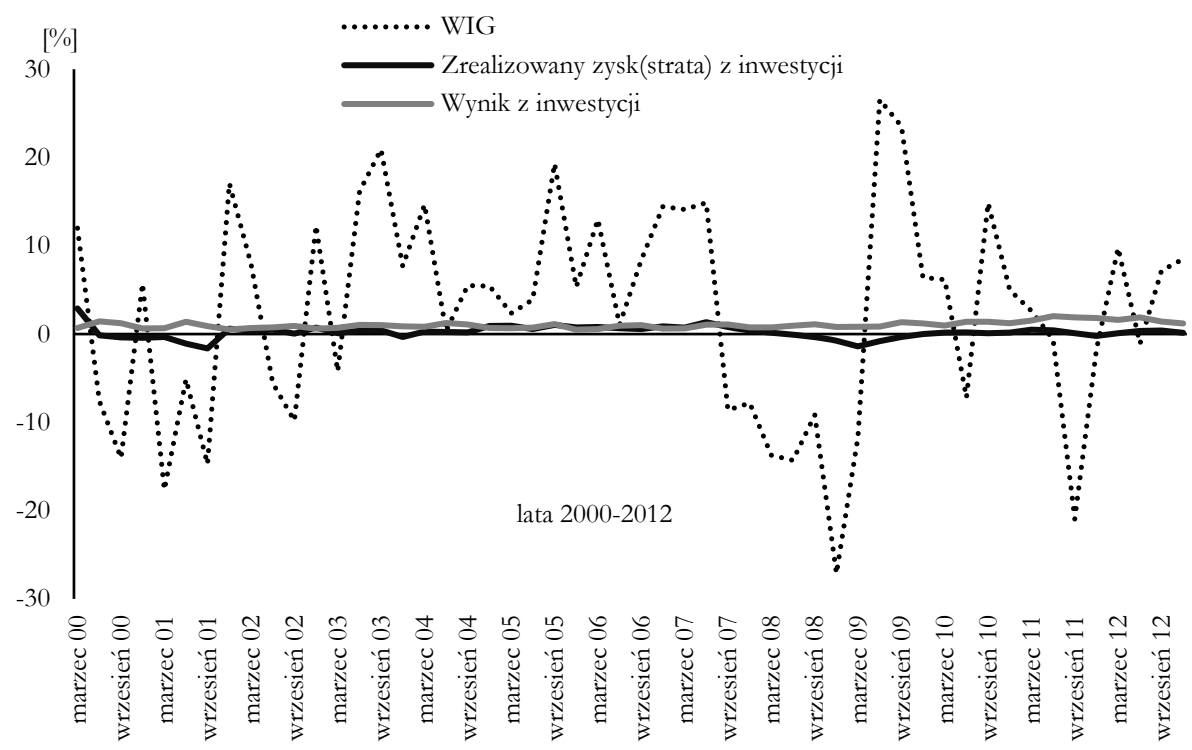

Źródło: opracowanie własne.

Z porównania parametrów statystyki opisowej (tabela 2.) można wnioskować, że zmienność wyniku finansowego otwartych funduszy emerytalnych była mniejsza w badanym okresie od zmienności przyjętych wzorców odniesienia w postaci indeksów giełdowych WIG oraz WIG20. Ich rozkłady były bardziej skupione wokół wartości średniej i większa ich liczba przypadała powyżej średniej. To jednak skutkuje średnio niższymi wynikami niż było to możliwe do uzyskania na rynku, np. inwestując w portfel odzwierciedlający strukturalnie indeksy giełdowe. Mniejsza zmienność (ryzyko) uzyskiwanych wyników oraz ich niższa wartość jest rezultatem struktury aktywów, które, oprócz akcji, obejmują także obligacje. Z tego względu fundusze emerytalne bardziej przypominały fundusze inwestycyjne stabilnego wzrostu, w których przypadku udział akcji w portfelu nie przekracza zwykle $40 \%$ wartości aktywów. 
RYSUNEK 4.

Zmienność wyniku finansowego oraz niezrealizowanego zysku (straty) z wyceny inwestycji otwartych funduszy emerytalnych na tle zmienności wzorca odniesienia (indeks WIG) w latach 2000-2012

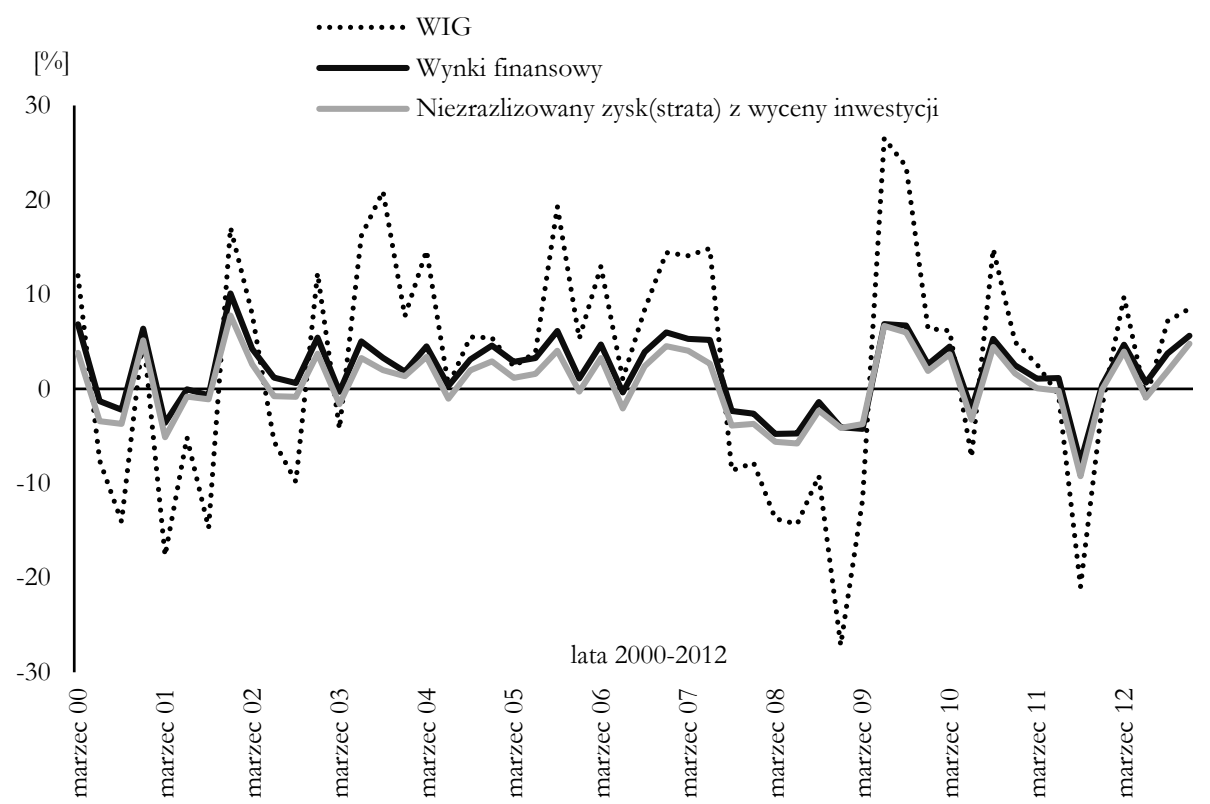

Źródło: opracowanie własne.

TABELA 2.

Statystyki opisowe rozkładów empirycznych składowych wyniku finansowego otwartych funduszy emerytalnych oraz stóp zwrotu indeksów giełdowych (WIG, WIG20), w ujęciu kwartalnym, w latach 2000-2012

\begin{tabular}{|c|c|c|c|c|c|c|c|c|c|c|}
\hline \multirow[b]{2}{*}{ Wyszczególnienie } & \multirow[b]{2}{*}{ Średnia } & \multirow{2}{*}{$\begin{array}{l}\text { Odchy- } \\
\text { lenie } \\
\text { stan- } \\
\text { dardo- } \\
\text { we } \\
\end{array}$} & \multicolumn{5}{|c|}{ Percentyl } & \multirow[b]{2}{*}{ Skośność } & \multirow[b]{2}{*}{ Kurtoza } & \multirow{2}{*}{$\begin{array}{c}\text { Współ- } \\
\text { czynnik } \\
\text { zmien- } \\
\text { ności }\end{array}$} \\
\hline & & & 0,05 & 0,25 & 0,5 & 0,75 & 0,95 & & & \\
\hline Wynik z inwestycji & 1,06 & 0,61 & 0,51 & 0,70 & 0,95 & 1,29 & 2,03 & 7,62 & 125,92 & 0,57 \\
\hline $\begin{array}{l}\text { Zrealizowany zysk } \\
\text { (strata) z inwestycji }\end{array}$ & 0,35 & 2,17 & $-1,55$ & $-0,15$ & 0,25 & 0,75 & 1,99 & 16,67 & 394,44 & 6,19 \\
\hline $\begin{array}{l}\text { Niezrealizowany zysk } \\
\text { (strata) z inwestycji }\end{array}$ & 0,52 & 3,94 & $-5,81$ & $-1,84$ & 0,96 & 3,18 & 5,72 & 0,37 & 12,88 & 7,54 \\
\hline Wynik finansowy & 2,00 & 4,91 & $-4,61$ & $-0,36$ & 2,26 & 4,84 & 6,83 & 5,12 & 67,88 & 2,45 \\
\hline WIG & 2,50 & 11,95 & $-16,04$ & $-7,29$ & 5,15 & 12,05 & 20,03 & $-0,29$ & $-0,44$ & 4,78 \\
\hline WIG20 & 1,49 & 12,39 & $-20,61$ & $-7,70$ & 3,44 & 8,93 & 20,35 & $-0,24$ & $-0,44$ & 8,30 \\
\hline
\end{tabular}

Źródło: opracowanie własne. 
Uzyskiwane przez otwarte fundusze emerytalne wyniki z działalności inwestycyjnej sa kształtowane przez zmienność rynku kapitałowego. Kryzys finansowy 2007/2008 nie pozostał bez wpływu na ich wyniki (rysunki 3. i 4.), lecz przede wszystkim wpływ ten miał charakter przejściowy. Uzyskiwany wynik z inwestycji potwierdza także, że koszty działalności inwestycyjnej w pełni były pokrywane z przychodów z lokat, a więc nie obciążały kapitału powstającego $\mathrm{z}$ wpłacanych składek. Z przeprowadzonych szacunków wynika również, że przeciętna roczna stopa zwrotu netto (czyli po uwzględnieniu opłaty dystrybucyjnej), mierzona od początku 2000 roku do końca 2012 roku, wyniosła dla wszystkich funduszy łącznie $12,6 \% \mathrm{w}$ skali roku. Można więc stwierdzić, że tworzenie realnego kapitału emerytalnego przez otwarte fundusze emerytalne przynosi wartość dodaną przyszłym emerytom. Jednak ocenę ich funkcjonowania utrudnia szczególny sposób ich powiązania z finansami publicznymi i długiem publicznym generowanym przez coroczne deficyty budżetu państwa.

\section{System emerytalny a finanse publiczne w kontekście kryzysu fiskalnego}

Kryzys fiskalny wiaże się z taką sytuacją w polityce fiskalnej, w której państwo albo nie jest w stanie dalej obsługiwać długu publicznego bez drastycznych cięć w wydatkach, albo nie jest w stanie realizować swoich zadań bez konieczności wstrzymania obsługi spłaty tego długu. Pierwszym przejawem rodzącego się kryzysu fiskalnego jest przekroczenie norm ostrożnościowych, mierzonych zwykle poziomem zadłużenia w relacji do produktu krajowego brutto. Bezpośrednim skutkiem nadmiernego zadłużenia jest konieczność wyboru między realizacją zadań państwa a utrzymaniem wypłacalności.

Jedną z przyczyn długu publicznego w Polsce są zmiany strukturalne, spowodowane nadmiernymi w stosunku do dochodów wydatkami państwa związanymi z przekształceniami społeczno-ekonomicznymi po 1989 roku. Szczególną rolę w tym obszarze odgrywają ubezpieczenia społeczne, a zwłaszcza ubezpieczeniowa część systemu emerytalnego zarówno pracowniczego, jak i rolniczego.

Ponieważ państwo jest gwarantem wypłaty świadczeń emerytalnych, niedobór własnych środków funduszy finansujących te świadczenia jest uzupełniany dotacją wyrównawcza. Od 1999 roku Fundusz Ubezpieczeń Społecznych, a w zasadzie jego subfundusz emerytalny, znalazł się w nowej sytuacji związanej z reformą emerytalna. Część składki, wpłacanej na ubezpieczenie emerytalne, jest przekazywana do otwartych funduszy emerytalnych, stąd powstaje luka w przypisie składki, którą uzupełnia się dopłatą (do 2003 roku dotacja) z tytułu przekazania składek do funduszy kapitałowych. Można określić tę sytuację jako dodatkowy koszt społeczny reformy emerytalnej, którego skutkiem jest wzrost wydatków z budżetu państwa na zrównoważenie repartycyjnej części systemu emerytalnego. $Z$ tego powodu łączny udział dotacji do funduszy emerytalnych (t). Funduszu Ubezpieczeń Społecznych oraz Funduszu Emerytalno-Rentowego) w wydatkach budżetu państwa wzrósł z 16,1\% w 1999 roku do 26,4\% wydatków w 2004 roku i utrzymywał się w granicy powyżej $21,7 \%$ do $25,7 \%$ do 2011 roku (rysunek 5.). Należy zwrócić uwagę na to, że jest to zasadniczo jedno z zadań państwa, które absorbuje od 20 do 
25\% jego wydatków budżetowych, przy równoczesnym posiadaniu przez te programy emerytalne własnych dochodów, wyodrębnionych z dochodów publicznych.

RYSUNEK 5.

Dofinansowanie FUS oraz FER w relacji do wydatków budżetowych, w latach 1999-2012 (w \%)

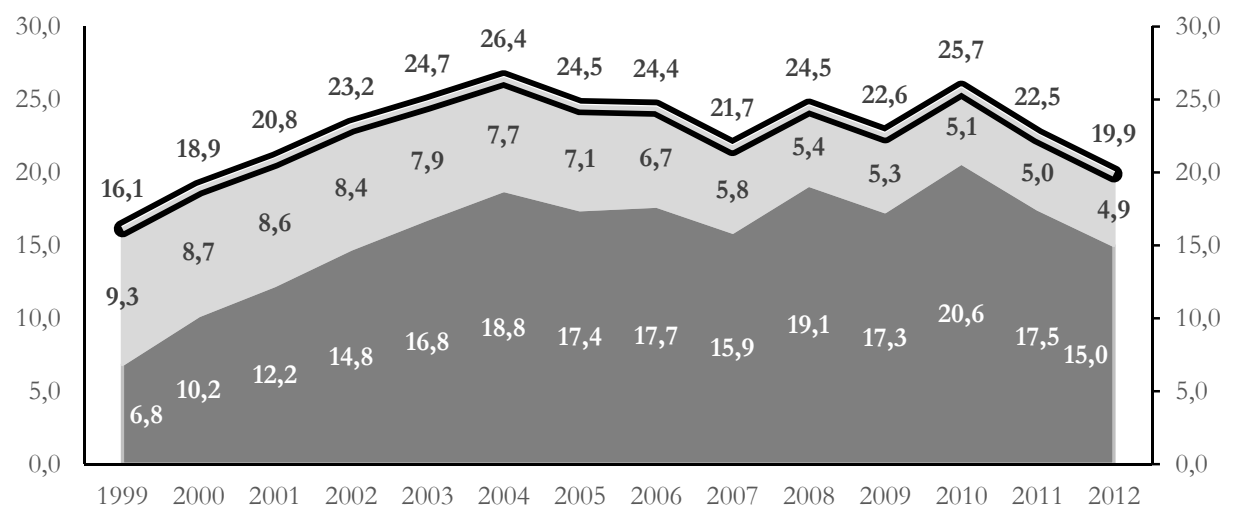

Źródło: opracowanie własne na podstawie danych GUS i ZUS.

Ponieważ analizowane fundusze repartycyjne (Fundusz Ubezpieczeń Społecznych oraz Fundusz Emerytalno-Rentowy) nie wykazywały nadwyżki finansowej w żadnym z kolejnych lat budżetowych 1999-2012, można przyjać, że tworzą własny dług względem budżetu państwa. Gdyby przyjąć takie założenie, okazałoby się, że głównym czynnikiem generowania długu publicznego w Polsce są właśnie ubezpieczenia społeczne (rysunek 6.). Można więc uznać, że obecną przyczyną strukturalną corocznego deficytu budżetowego i długu publicznego sa ubezpieczenia społeczne. Jednym z powodów tego stanu rzeczy jest reforma emerytalna i wspomniany wyżej jej koszt społeczny, pokrywany ze środków budżetowych przez wszystkich obywateli płacących podatki. 
RYSUNEK 6. Skorygowany dług sektora rządowego i sektora ubezpieczeń społecznych w latach 1999-2012

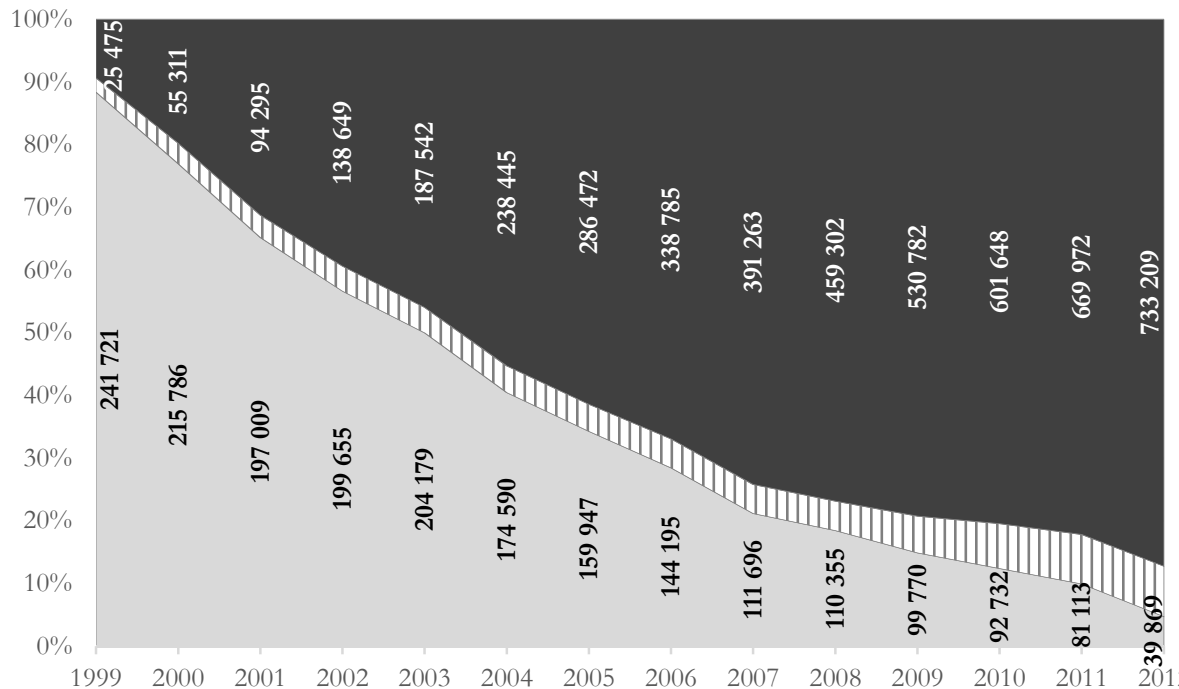

- skorygowany dług sektora ubezpieczeń społecznych

$\square$ dług sektora samorządowego

$\square$ skorygowany dług sektora rządowego

Źródło: opracowanie własne.

Jednym z zaproponowanych rozwiązań ograniczenia przyczyn strukturalnych deficytu budżetowego i długu publicznego było zmniejszenie transferu składki do otwartych funduszy emerytalnych, co spowodowało zmniejszenie udziału dotacji do Funduszu Ubezpieczeń Społecznych do poziomu 15\% wydatków budżetowych. Otwarte fundusze emerytalne są nie tylko źródłem kapitału dla przedsiębiorstw, ale równocześnie nabywcą długu publicznego. W strukturze ich aktywów papiery udziałowe stanowiły nie więcej niż 40\%, a w roku kumulacji kryzysu finansowego zmniejszyły się do $21,4 \%$. Dominującym składnikiem aktywów są obligacje i bony skarbowe. Ich udział na koniec 2012 roku wyniósł 44,8\%, ale w roku 2008 te instrumenty stanowiły 73,5\% wartości aktywów (rysunek 7.). 
RYSUNEK 7. Struktura aktywów otwartych funduszy emerytalnych w latach 1999-2012 (w \%)

\begin{tabular}{c}
\cline { 2 - 5 } 2012 \\
\cline { 2 - 5 } 2011
\end{tabular}

Źródło: opracowanie własne na podstawie danych KNF.

Na koniec 2012 roku wartość zakumulowanego kapitału emerytalnego przez otwarte fundusze emerytalne wyniosła ponad $271 \mathrm{mld} z \nmid, \mathrm{z}$ tego prawie $122 \mathrm{mld}$ zł stanowił nabyty dług Skarbu Państwa.

Dlatego też w perspektywie dalszego wzrostu długu publicznego jednym z przyjętych rozwiązań pod koniec 2012 roku jest umorzenie części tego długu z aktywów 
otwartych funduszy emerytalnych i równoczesne przeniesienie zobowiąań wobec przyszłych emerytów do finansowania repartycyjnego.

\section{Podsumowanie}

Funkcjonowanie systemu emerytalnego nie jest wolne od zmienności czynników: demograficznych, społecznych czy ekonomicznych. Wykorzystanie modelu kapitałowego finansowania świadczeń emerytalnych powoduje, że system ten staje się interesariuszem rynkowego systemu finansowego i ze względu na swoja pozycję ponosi skutki kryzysu finansowego, jednak mają one charakter przejściowy. Natomiast model kapitałowy finansowania emerytur umożliwia równowagę międzypokoleniową w redystrybucji dochodu w związku z realizacją celu systemu emerytalnego, a równocześnie zapewnia gromadzenie kapitału, który może być wykorzystany w procesie rozwoju gospodarczego (służy pokoleniu aktywnemu i emerytalnemu równocześnie). Model repartycyjny finansowania emerytur w przypadku realizacji ryzyka systemowego - na który jest bardziej wrażliwy - wymaga interwencji ze strony władzy publicznej, której skutkiem może być powiększenie długu publicznego oraz obciążenie bieżącego i kolejnych pokoleń jego spłatą, a więc jest źródłem kryzysu fiskalnego. Zabezpieczenie interesariuszy systemu emerytalnego może odbywać się za pomocą gwarancji wypłacalności funduszy i/lub gwarancji minimalnej emerytury, które wymagają systemowych rozwiązań regulacyjnych, opartych na modelu finansowania kapitałowego.

Z perspektywy możliwości realizacji koncepcji zrównoważonego rozwoju wybór kapitałowego modelu finansowania emerytur jest bezpieczniejszy, gdyż uwalnia budżetowe środki na potrzeby finansowania zadań i projektów społecznie pożądanych, a niemożliwych lub trudnych do realizacji z funduszy prywatnych. Specyfika sytuacji polskich finansów publicznych, powodująca odwrót od kapitałowej metody finansowania emerytur, może przynieść korzyści obecnemu pokoleniu aktywnych zawodowo, z uwagi na możliwość poprawy ich sytuacji materialnej za pomoca programów polityki społecznej, na które moga być przeznaczone dodatkowe „rezerwy”, uwolnione dzięki zmniejszeniu poziomu długu publicznego, jednak większe korzyści będą osiagnięte dzięki wydatkowaniu tych funduszy na wydatki infrastrukturalne, ponieważ dadzą one korzyści także przyszłym pokoleniom.

\section{Literatura}

Blake D. 2006 Pension economics, Willey, New York.

Bohn H. 2006 Who bears what risk? An intergenerational perspective, [in:] Restructuring retirement risk, D. Blitzstein, O. S. Mitchell, S. P. Utkus (eds.), Oxford University Press, New York.

Góra M. 2003 System emerytalny, PWE, Warszawa.

Halsen J. A. 2003 Mutual funds, Blackwell Publishing, Malden-Oxford-Carlton. 
Kania P. 2011 Finansowe skutki reformy emerytalnej, [w:] Kontrowersje wokót finansów, T. Famulska, J. Nowakowski (red.), Difin, Warszawa.

Kania P. 2012 Ubezpieczenie społeczne a mechanizm jego finansowania - funkecja çy dysfunkicja w rozwoju gospodarczym, [w:] System finansowy a rozwój gospodarczy. Szanse i zagrożenia, B. Filipiak, J. Fila (red.), Difin, Warszawa.

Ksz̧taltowanie teorii i wdrożeniowe aspekty zrównoważonego rozwoju, 2011, B. Poskrobko (red.), Wydawnictwo Wyższej Szkoły Ekonomicznej w Białymstoku, Białystok.

Skipper H. D., Kwon W. J. 2007 Risk management and insurance. Perspectives in a global economy, Blackwell Publishing, Malden-Oxford-Carlton.

Solarz J. K. 2008 Zarzqdzanie ryzykiem system finansowego, Wydawnictwo Naukowe PWN, Warszawa.

Zarzadzanie ryzykiem 2007, K. Jajuga (red.), Wydawnictwo Naukowe PWN, Warszawa. 